\title{
Don Quixote de la Corte: Serial litigants, emotions, and access to justice
}

OÑAti Socio-Legal Series Volume 11 Issue 2 (2021), 503-533: “ToO Much Litigation?”: Facts, REASONS, CONSEQUENCES, AND SOLUTIONS

DOI LINK: HTTPS://DOI.ORG/10.35295/OSLS.IISL/0000-0000-0000-1117

RECEIVED 02 SEPTEMBER 2019, ACCEPTED 09 DECEMBER 2019

\author{
EYAL KATVAN* \\ BOAZ SHNOOR* ID
}

\begin{abstract}
Serial litigants are a well-known phenomenon. This article deals with this phenomenon on two different levels using Israel as a test-case. First, we analyze the impact they have on the judicial system as a whole, and the institutional responses the judicial system uses in order to deal with serial litigants as well as the impact (both positive and negative) such serial litigants have on other litigants. Second, we analyze the personal motives of serial litigants and identify their common denominators, as well as what differentiates them. In this regard the article offers a unique approach by presenting the perspective of serial litigants and the human dimension behind their claims. We then show that serial litigants do not constitute a monolithic group, and suggest that courts have to take the differences between them into account. We further propose the formulation of systemic tools that take into account both the negative and the positive aspects of serial litigants in order to strike a proper balance between the optimal allocation of resources, and the right of access to justice.
\end{abstract}

\section{Key words}

Courts; serial litigants; access to justice

\footnotetext{
The authors declare that the research published in this paper was done according to the Statement Of Principles Of Ethical Research Practice of the SLSA, as published in https://www.slsa.ac.uk/images/slsadownloads/ethicalstatement/slsa $\% 20$ ethics $\% 20$ statement $\% 20$ final $\% 5$ B1\%5D.pdf

${ }^{*}$ Eyal Katvan is a senior lecturer at the Peres Academic Center. He specializes in the fields of bioethics, law and medicine, the legal and medical professions, legal history, and the history of medicine. Peres Academic Center, Shimon Peres St 10, Rehovot, Israel. Email address: drkatvan@gmail.com

* Boaz Shnoor is a senior lecturer at the Academic Center for Law and Science. Boaz teaches and researches libel law and honor, tort law, environmental law, the legal profession, and law and psychology. He has published two books and many articles on these subjects. Center for Law and Science, 5 Margoa St., Hod Hasharon, P.O.B 261 Hod Hasharon 4510201, Israel. Email address: boazs@mishpat.ac.il
} 


\section{Resumen}

Es muy conocido el fenómeno de los demandantes en serie. Este artículo se ocupa de dicho fenómeno en dos niveles, utilizando Israel como caso de prueba. Primero, analizamos el impacto de los demandantes en serie en el sistema judicial, y las respuestas institucionales que utiliza el sistema judicial para tratar con los demandantes en serie, así como el impacto, tanto positivo como negativo, que dichos demandantes en serie ejercen entre sí. En segundo lugar, analizamos los motivos personales de los demandantes en serie e identificamos sus denominadores comunes y sus diferencias. A ese respecto, el artículo ofrece un enfoque original, porque presenta el punto de vista de los demandantes en serie y la dimensión humana detrás de sus reclamaciones. Después, mostramos que los demandantes en serie no constituyen un grupo monolítico, y sugerimos que los tribunales deben tomar en cuenta las diferencias entre ellos. Además, proponemos la creación de herramientas sistemáticas que consideren los aspectos positivos y negativos de los demandantes en serie, para así llegar a un equilibrio entre la dotación óptima de recursos y el derecho de acceso a la justicia.

\section{Palabras clave}

Tribunales; demandantes en serie; acceso a la justicia 


\section{Table of contents}

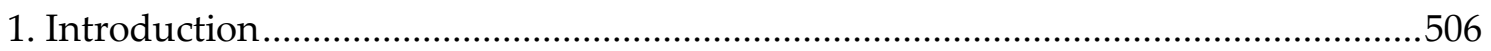

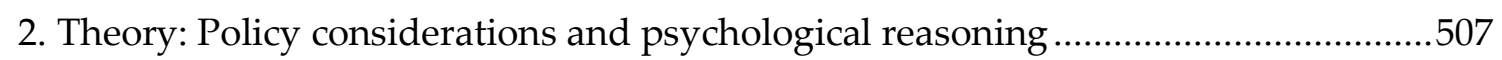

2.1. Policy considerations and systemic aspects..................................................508

2.2. Psychological explanations and aspects...........................................................509

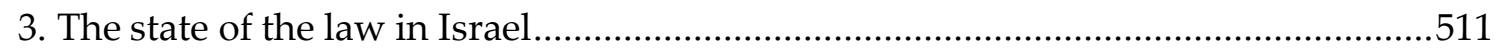

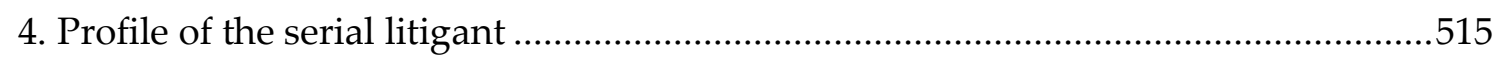

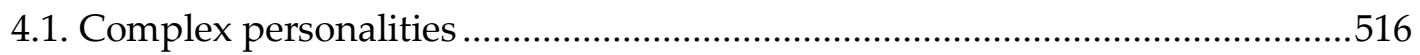

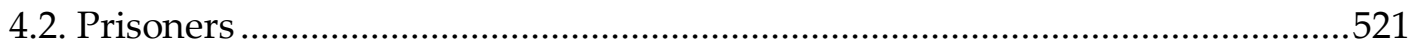

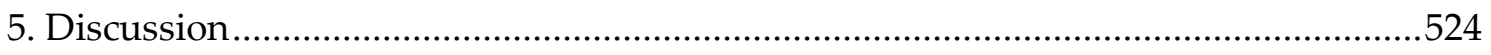

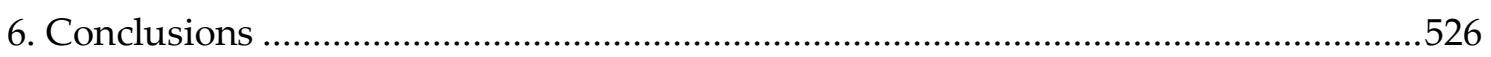

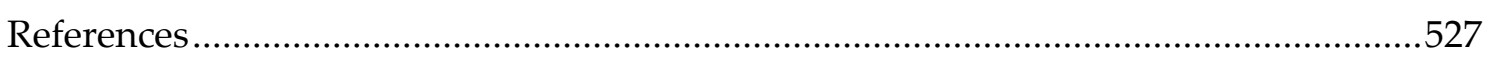

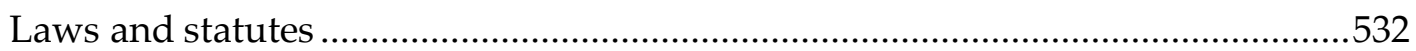

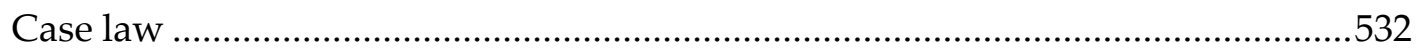




\section{Introduction}

As early as the nineteenth century, England's judicial system was forced to contend with a serial litigant, Alexander Chaffers, a solicitor who harassed the courts with incessant lawsuits and ignored orders that he reimburse defendants for court costs. To put a stop to his endless lawsuits, the British Parliament enacted the Vexatious Actions Act of 1896 (Taggart 2004).. ${ }^{1}$ In Australia, the lawsuits brought by Rupert Frederick Millane resulted in the adoption of similar legislation more than 85 years ago (Lester and Smith 2006), and Texas has been addressing and continuously amending its approach to the problem of vexatious litigants for 150 years (Colby 2000). Today many countries have adopted legislation authorizing courts to prevent litigants from repeatedly filing vexatious claims (see, for example, in Canada, Federal Court Act 1985 (s. 40(1)); in Australia, Vexatious Proceedings Act 2008 (New South Wales), Vexatious Litigant Act 1981 (Queensland); in New Zealand, Judicature Act 1908 (s. 88B); in California, Code of Civil Procedure S. 391.1). In 2018 proposed legislation along these lines was introduced in Israel, although it has yet to become law. Nonetheless, on several occasions the courts themselves have issued orders limiting access to the court system on the part of serial litigants who are perceived as initiating "too much litigation" and further overburdening the courts. ${ }^{2}$

Serial litigants - that is, individuals who file dozens or hundreds of futile lawsuits and legal petitions annually, disproportionately engaging the courts relative to other citizens - are neither a new phenomenon nor a strictly Israeli one, as indicated by the various appellations they have earned over the years, such as "vexatious litigants" or "querulants." Although they see themselves as pursuers of justice, other people attach psychiatric labels to them, attributing them with "delusions of injustice" that result in harm to the judicial system and litigants (Elizur et al. 1999, p. 84).

There are two perspectives in the assessment of serial litigants. ${ }^{3}$ On the one hand, this is a social phenomenon with a strong impact on the judicial system. For example, the ten leading serial litigants in Israel are collectively responsible for thousands of judicial decisions every year. ${ }^{4}$ In so doing, they increase the volume of court cases, possibly denying other litigants their "day in court" (Addad 2013, pp. 255-256). On the other hand, serial litigants are few in number. ${ }^{5}$ Therefore, it is appropriate to view them not as a "phenomenon" but as individuals, and to respond to them on an individual basis (Whalen-Bridge 2019).

\footnotetext{
${ }^{1}$ Today the authority to issue a civil proceedings order, a criminal proceedings order or an all-proceedings order lies with the High Court, in accordance with Section 42 of the 1981 Senior Courts Act. In addition, judges have the authority to issue orders with respect to the cases before them, or in certain cases the entire district. These orders are, however, limited to a period of two years (with some options for extension).

2 For a comprehensive survey of the options available to a defendant who wishes to limit access to the courts by a vexatious litigant in Israel, see Addad 2013, pp. 249-301.

${ }^{3}$ The definition of a serial litigant rests on two interrelated elements. The first relates to the personality of the complainant: someone who tends to file numerous complaints, often using harsh language. The second element relates to the nature of the complaints themselves: complaints that are futile from the outset.

${ }^{4}$ In Australia it is estimated that serial litigants account for less than $1 \%$ of all litigants, but addressing their claims requires 15-30\% of the courts' resources (Mullen and Lester 2006).

${ }^{5}$ For example, according to the HM Courts and Tribunals Service of England and Wales (2019b), since 1950 less than 200 individuals have been declared "vexatious litigants, banned from starting court cases without permission", and only about eighty general civil restraint orders are currently in force (HM Courts and Tribunals Service of England and Wales 2019a).
} 
Many times, comparing the legal profession(als) to the medical profession(als) can be quite illuminating (e.g. Katvan 2013, Katvan and Shnoor 2017). In this case, serial litigants can be compared to people who suffer from hypochondria. ${ }^{6}$ Such people, just like serial litigants, can, and should be, treated on an individual basis, even though their behavior is a social phenomenon that takes a high toll from the health system in a reality of scarce health resources (Katvan et al. 2017), and although this behavior burdens health personnel with insignificant complaints (Ramachandra 2013, Albarracin 2015). ${ }^{7}$

In this study we attempt to integrate the two different perspectives of the phenomenon (Am Shalem v Lifschits, 2003, Bryant 2019) - the individualistic and the systemic - while illustrating the issue in Israel's judicial context, and comparing it to the medical and psychologic treatment of hypochondria. We will examine the methods by which Israel's legal system has sought to address serial litigants; then we will present the most prominent Israeli serial litigants and attempt to identify their motives. The article offers a unique approach by presenting the perspective of serial litigants and the human dimension behind their claims. We will identify their common denominators, as well as what differentiates them. As we shall see, "serial litigants" do not necessarily constitute a monolithic group, and courts have to take the differences between them into account (Whalen-Bridge 2019). Finally, we propose the formulation of systemic tools that take into account both the negative and the positive aspects of serial litigants in order to strike a proper balance between the optimal allocation of resources, and the right of access to justice. This approach is based on an understanding that labeling litigants as "serial" does not, by itself, address the problem, and that restricting their right of access to justice would not necessarily be effective and could, in fact, thwart important, justifiable claims and prevent the court from exercising its social role of containment.

We wish to underscore that this article does not engage in a psychological "diagnosis" of serial litigants. ${ }^{8}$ The examples we present indicate that there are different categories of serial litigators, each of which has common denominators. Our description of cases is also intended to illustrate the human dimension of serial litigants - a dimension that is sometimes overlooked by the judicial system, which rightly strives to be efficient and reduce the burden on courts. It is further intended to illustrate the hardship these cases pose for judges, who endure not only the judicial burden but also a personal burden because they must cope with long-winded court documents that are not always filed properly and tend to use convoluted language that is often harsh and occasionally directed at the judges themselves.

\section{Theory: Policy considerations and psychological reasoning}

In this section we examine the policy considerations that shape the social institutional response to the phenomenon of serial litigants, and we point to potential psychological explanations aimed at understanding the personal motives of some of these litigants.

\footnotetext{
6 The DSM-5 uses the term "somatic symptom disorder" instead of "hypochondria" (American Psychiatric Association 2013, at p. 310). However, since most of our readers are more familiar with the term "hypochondria", we preferred it over the new and more accurate term.

${ }^{7}$ Interestingly, just like serial litigation, hypochondria suffers from lack of theoretical analysis (Ramachandra 2013, Albarracin 2015).

${ }^{8}$ This is one of the reasons behind our choice to disguise the litigants' identities.
} 
Both aspects will be surveyed briefly as they are supported by extensive scholarship, in contrast to the examples presented later, which focus on the personal and human element that is relatively lacking in the research on serial litigants.

\subsection{Policy considerations and systemic aspects}

The main policy considerations that emerge from the activity of serial litigants came to light as early as 1896, when the British Parliament enacted the Vexatious Actions Act of that year (Taggart 2004). To this day these considerations continue to surface, almost unchanged, in court rulings and legislation on the matter. ${ }^{9}$

On the one hand, all individuals have the right to appear in court, present their case, and receive a fair trial. This right, the right of access to justice, is constitutionally enshrined in some states including Israel (Rabin 1998, Barak 2013). Any restriction on this right is regarded as particularly problematic because the right is a condition for the realization of all other rights (Arpal v Kalil, 1997, p. 632, Addad 2013, p. 263, Courts (vexatious litigants) Memorandum Bill 2018). If an individual is denied access to court, then even in the event of a genuine injury, that person will be unable to receive judicial relief and consequently other rights would be trampled, all the more so when that individual is in a vulnerable state such as bankruptcy, mental illness, or incarceration. Similarly, people who suffer from hypochondria are still entitled to medical treatment, and denying this right might result in severe consequences to the patient (and to her environment, if she suffers from a contagious disease).

In addition, allowing serial litigants to have their day in court serves other public goals. First, a relatively large number of serial litigants are people in total institutions: prisons and mental institutions. Some of the claims they make have merit, and the impact these claims have, go far beyond the serial litigant herself and might change procedures which effect the whole population staying in prisons or mental institutions. The existence of these serial litigants and the fact that the court take them seriously, might serve as an important safeguard to protect a very weak and silenced population.

Second, allowing serial litigants their day in court by addressing their claims on the merits (even if rejecting their claims as meritless in the end) might serve to lower the chance that the serial litigant will turn her anger and frustration into verbal and physical violence (Abel 1973, Merry 1990, 38, 176, Blee and Billings 1996). Allowing these claims enables the ventilation of hard feelings in court and tunneling them into socially acceptable channels (Katvan and Shnoor 2020).

On the other hand, when an individual exploits the right of access to justice for adverse purposes, others are harmed: defendants must then devote time and financial resources to a baseless claim, often with no compensation (certainly not full reimbursement) for these wasted resources. Moreover, a legal complaint in itself is often a source of anguish for defendants and might cause severe harm to their reputation. ${ }^{10}$ In the case of claims

\footnotetext{
9 See the discussion on case law and proposed legislation in Israel below, in the third section.

10 A lawyer defending a client against a serial litigator might also become a target. For example, "Attorney Bach claims that the present petition is one of many forms of harassment he has experienced during the past decade, as Leibel has initiated dozens of frivolous proceedings in various courts, usually recycling the same claims." (Leibel v Rotschild, 2016).
} 
against the state, the harm mainly takes the form of time spent by attorneys for the state who must address these cases at the expense of others; this is, of course, compounded by harm to the public: Judicial time is a precious and limited resource that ought to be allocated in the most efficient manner possible. When individuals exploit this resource for adverse purposes, they prevent others from using the judicial resource, cause delays in the justice system, and effectively deny others the right of access to their own justice (Addad 2013, pp. 263-269). Moreover, in most cases serial litigation is vexatious in nature and difficult to manage, thus creating hardship for judges and making their work environment less pleasant. An unpleasant work environment, in turn, decreases judicial efficiency generally, which affects the entire system (Ben Noon et al. 2015). In a similar way, people who suffer from hypochondria adversely affect the well-being of their doctors, thus effecting the whole health system (Ramachandra 2013, Albarracin 2015).

Judge Ben-Ito summarized the situation concisely in a 1969 article: "There are a number of people of this sort, with whom the courts are quite familiar. Sometimes they file dozens of lawsuits against the same defendant, making his life hell. During the course of the trial they turn the courtroom into a circus. And the court is truly powerless because it is legislatively obligated to conduct the trial (...). Not only is there no real option for making the complainant cover the costs, but the court also refrains from imposing sanctions on a disturbed or mentally ill individual who believes he is right and is only driven by his illness. The court has no authority to consider the question of his sanity" (Ben-Ito 1969, p. 523).

\subsection{Psychological explanations and aspects}

In the past, the pursuit of serial litigation that does not stem from strategic or rational considerations on the part of the plaintiff was classified by The Diagnostic and Statistical Manual of Mental Disorders (DSM) as a distinct mental disorder. According to the literature, psychological diagnoses that referred directly to this disorder were rare in England but more prevalent in Germany and Scandinavia (Rowlands 1988). ${ }^{11}$ The infrequency of this diagnosis is perhaps the reason that it was omitted from later editions of the DSM, and today it is mentioned only incidentally as a subtype of delusional disorder (which is part of the schizophrenia spectrum), in which "[t]he affected individual may engage in repeated attempts to obtain satisfaction by legal or legislative action" (American Psychiatric Association 2013, pp. 91-92, Gerevich and Ungvari 2015, p. 80). Nonetheless, the literature contains references linking serial litigation to three different mental disorders.

The first disorder is delusional disorder mentioned above. People suffering from delusional disorder. According to the DSM, "individuals with persecutory delusions are often resentful and angry and may resort to violence against those they believe are hurting them" (American Psychiatric Association 2013, p. 92).

The second disorder that the literature associates with serial litigation is abnormal and excessive suspiciousness, or querulent paranoia (Freckelton 1988, Mullen and Lester 2006, Lester and Smith 2006). Plaintiffs with this condition suffer from false delusions

11 The prevalence of this diagnosis in Scandinavian countries is reflected, for example, in the fact that Swedish has a special word, rattshaverist, to designate a person who becomes a serial litigant after suffering a loss in court (Diesen 2008). 
resulting in suspicion and paranoia as well as a defensiveness that leads them to engage in serial litigation. Some literature shows suggests that serial litigants suffering from this disorder might even resort to violence or self-harm (Lévy et al. 2017), and aside from addressing the litigation through the system, individual treatment of the serial litigant is recommended (Mullen and Lester 2006).

The third disorder associated with serial litigation is obsessive-compulsive disorder (OCD). According to DSM-V, OCD is characterized by obsessive thoughts, compulsive behavior or both (American Psychiatric Association 2013, pp. 235-237). In the case of serial litigants, the obsessive thoughts are linked to a personal perceived injustice committed in the past or a persistent desire to attain absolute justice. The compulsive behavior takes the form of litigation (Addad 2013, p. 250).

The above indicates that it is difficult to diagnose this phenomenon, and since judges are unqualified to diagnose litigants and are unauthorized to order that civil litigants be evaluated without their consent, they face a greater difficulty (Am Shalem v Lifschits, 2003). ${ }^{12}$ Litigants who suffer from a mental disorder, might persistently follow their own course regardless of any judicial response. Indeed, such a response might exacerbate their condition since it might make the litigant feel that the judge is trying to hurt her, and a litigant who does not receive judicial redress might resort to violence (American Psychiatric Association 2013, p. 92). The story of Michael Kohlhaas, the titular character of a novella by Heinrich von Kleist, provides an example. Having despaired of achieving justice through the court system, Kohlhaas recruits an army and launches an armed rebellion, at the cost of his and his family's lives (Gerevich and Ungvari 2015). A similar phenomenon is the phenomenon of patients who suffer from delusions and turn to a physician, demanding that a trial be held to determine the source of their persecution, since "a patient who feels that 'there is no justice in this state' will stop turning [to courts, the president, or others]" and turn instead to other entities (Lévy 1997, pp. 15-16).

One of the reasons that civil courts provide a forum for dispute resolution is to prevent conflicts from "spilling" into the street. In this sense the court system, perhaps unwittingly, engages in the management and channeling of emotions (Katvan and Shnoor 2020). Similarly, in administrative and public law one of the roles of the judicial system is to facilitate "venting" complaints, particularly for those in total institutions (such as prisons or psychiatric facilities). ${ }^{13}$ Thus, unwittingly or not, the judicial system serves as part of a therapeutic process for litigants, especially for victims in criminal courts. The well-known reference to one's "day in court" reflects this reality. Given the mental disorder from which some of the serial litigants suffer, restrictions on access to court could result in undesirable and unchecked expressions of emotion outside the courtroom after plaintiffs or petitioners realize that the legitimate avenue is no longer available.

In this context, the access to courts itself (and not winning the lawsuit), might have a beneficial therapeutic aspect. Similarly, the quality of the relationship between the

\footnotetext{
12 Supreme Court Justice Levy suggested that the Attorney General will consider limiting the plaintiff`s capacity to file claims and appointing a custodian to protect the plaintiff from himself (Am Shalem v Lifschits, 2003).

${ }^{13}$ On evaluations by and interaction with physicians as a vital means of relieving social pressure, especially in total institutions, see Waitzkin and Waterman 1974.
} 
doctor and the hypochondriac patient is more important in eliminating hypochondriac symptoms, than the quality of the medical treatment itself (Noyes et al. 2010, Albarracin 2015). On the other hand, one might argue that the courts' tolerance (just like the doctors' tolerance of the hypochondriac patient) serves as a positive reinforcement, causing the behavior to repeat itself.

\section{The state of the law in Israel}

In the present section we analyze Israeli case law relating to serial litigants and identify two approaches: the first is based on containment and forgiveness, and the second, more dominant approach is strict and prohibitive. In the next section we will present biographical sketches of several prominent serial litigants in Israel. The combined objective of the two sections is to underscore the two facets of the phenomenon - the systemic aspect and the personal aspect that represents the people behind the claims.

The first judicial decision involving an injunction against further proceedings in the case of a serial litigant was issued in the mid-1970s. The district court in that case ordered that Dov Alon, a serial litigant, be prevented from filing further petitions or appeals on a specific issue (Alon v State of Israel, 1975b). The Supreme Court granted the appeal against this ruling, holding that "by law, even troublesome individuals have the right of access to court, and it is not within our purview to lock them out." (Alon v State of Israel, 1975a) The court noted that there are various sanctions against vexatious litigants, which the judge could impose in this case, but that the court has no authority to prevent a litigant from accessing the court. This early ruling reflects an extreme position, denying any authority to issue injunctions against serial litigants. As a result, presumably, there were no requests for such injunctions in the decades that followed. Only after a ruling was issued on another matter, identified a basis of authority for the issuance of injunctions against further proceedings, did courts begin to revisit the question. Nonetheless, the ruling on Dov Alon has reverberations to this day.

In 1996 the court addressed a slightly different issue, which later served as a basis for proceedings on our matter as well (Friskel v Orenstein, 1996). In this case it was asked to consider an injunction aimed at preventing a lawsuit from being filed in other countries, after the issue had already been addressed in an Israeli court. The Supreme Court found two legal bases for such an injunction. The first was Section 75 of Israel's Courts Law, legislated after the ruling on Alon Dov, which holds, "Any court addressing a civil matter has the authority to issue a declaratory ruling, a performance order, a restraining order, an order for a specific remedy, or any other remedy, as it sees fit under the circumstances before it." The second basis was the inherent authority of the court. The court found, however, that "the discussion's starting point, which everyone accepts, is that denying a person access to the court is to be avoided to the extent possible, and that the utmost caution should be exercised in issuing such an order, reserving it strictly for extreme and exceptional cases." In light of its prioritization of every individual's right of access to justice, it therefore refrained from issuing the order in this case. ${ }^{14}$

\footnotetext{
14 This, referred to injunctions against litigation of the same issue in foreign courts. See also Inter-Lab inc. $v$ Israel Bio Engineering Project, 2003, Zomris v Weiss, 2004.
} 
In 2006 the Supreme Court registrar at the time, Yigal Mersel (currently director of the Courts Administration), issued a ruling that reflected growing recognition of considerations that justify injunctions against further proceedings (SH11). The ruling dealt with an exemption from fees. Justice Mersel denied the petition for an exemption, finding the underlining claim to be baseless and frivolous. In his decision he addressed both aspects of the phenomenon of serial litigants. In terms of the systemic social aspect, he found that the law permits not granting an exemption from fees to litigants who file frivolous claims (Bar-Am 2007), and that in fact it permits imposing additional fees and expenses (to be paid to the other party or the state) as well as the dismissal of such claims without consideration of the merits. ${ }^{15}$ At the same time, in terms of the personal aspect, he admitted that these measures were not effective against determined serial litigants. As such, he addressed the option of issuing an injunction against further proceedings. This discussion focuses on the systemic aspect of the phenomenon and overlooks the personal aspect. In terms of the merits of the matter, drawing on the aforementioned Dov Alon case and setting aside the ruling on injunctions against lawsuits in other countries, the court found that currently there is no basis for injunctions against further proceedings and noted that it may be appropriate for the legislature to create such a possibility.

Another milestone was set in 2011, with the actual issuance of an injunction against further proceedings. In this case $(Y v Y, 2010)$ the court was asked to issue an injunction preventing a prisoner's wrongful use of court proceedings to cause harm to his daughter. The case involved an ultra-orthodox prisoner serving a long sentence for sexually abusing his daughter. While incarcerated he began filing hundreds of baseless claims against her friends, neighbors, and teachers, in each case attaching a copy of his sentence, which detailed the acts he had committed against his daughter. His aim, which he achieved, was to violate her privacy without her being able to file suit against him (given that a violation of privacy in the context of legal proceedings cannot serve as a cause of action). The court referred to the case of Dov Alon, which did not provide a basis for an injunction, but in light of the Friskel case it found that it has the authority to issue such an injunction on the basis of both Section 75 of the Courts Law and its inherent authority. It held that even though the matter involves the violation of a constitutional right and that under such circumstances an injunction could be issued only in exceptional cases, nonetheless, if instituting proceedings would severely infringe on the rights of others, and if the sole purpose of initiating them was to cause harm, rather than secure a favorable verdict, then it would be appropriate to condition the initiation of proceedings regarding sexual abuses committed by the plaintiff against his daughter on a preliminary judicial ruling, so as to ensure that such proceedings would not cause severe and disproportionate harm to others. The court also addressed personal aspects, noting that a review board had determined that "the litigant suffers from a serious personality disorder, and he has admitted his deeds but completely lacks empathy for his daughter,

\footnotetext{
${ }^{15}$ In practice, courts so rarely invoke this authority against serial litigants, that when the president of the Supreme Court ordered a serial litigant to pay a sum equivalent to $€ 2,000$ after he had filed 13 frivolous claims within one day using harsh and threatening language (in a ruling issued on August 15, 2014), critical articles about the "phenomenon of costs" appeared in the press (Gueta 2014). See also Shammay (2018) who criticizes the Supreme Court for not imposing court costs, or imposing symbolic costs of less than €100, on serial litigants.
} 
the victim, or his family members." It further noted that there is a higher percentage of serial litigants among prisoners and among litigants in family court than among other population groups. The injunction issued in this case rested solely on the severe harm to individuals stemming from personal aspects, rather than any systemic harm caused by the litigant.

The first (limited) injunction based on systemic harm was issued in 2014, in a ruling by the Supreme Court president (chief justice) at the time, Justice Grunis, in the matter of a serial litigant by the name of VK. Under the terms of the injunction, the Registry Office would no longer accept petitions from this claimant regarding proceedings that had ended, and the court would not consider claims that use inappropriate language (VK8). This was a relatively limited injunction, as it still allowed VK to initiate new proceedings (if properly formulated). Nonetheless, it drew criticism from senior jurists who argued, among other things, that the Supreme Court president had acted without authority (Paz 2014).

Subsequent lower court rulings indicate that some judges were uncomfortable with the Supreme Court's decision, as evidenced by their narrow interpretation of it and reiteration of the argument about lack of judicial authority. In 2016, for example, the Tel Aviv District Court considered an appeal of a family court decision that barred a vexatious litigant, who had in fact interrupted proceedings and berated the court, from filing further claims. The District Court found that notwithstanding the VK ruling, the court lacks the authority to issue injunctions against further proceedings (Y.Y.E. v M.T., 2016).

The approach that requires the judicial system to adapt itself to serial litigants is further illustrated in a decision issued by the Ombudsman of the Israeli Judiciary (2016) with respect to a serial litigant. One of his suits filed as "expedited suit". However, the ruling was issued six months after the final summations in the case were filed. The serial litigant complained against the judge, who argued that the delay resulted from the actions of the serial litigant, who had greatly overburdened the court and during the proceedings had been extremely disruptive in his conduct toward anyone connected with the case. The ombudsman rejected this argument, stating that even if the facts were true, they could not justify infringement of the plaintiff's right to receive a timely ruling.

In contrast, on two occasions the president of the Tel Aviv-Jaffa District Court, Judge Orenstein, issued injunctions against further proceedings after holding that he had the authority to do so. The first case involved an unrepresented litigant who filed a class action suit after the clients of a particular lawyer had filed a similar class action suit. In such cases a court must determine which of the two class actions will continue and which will be ceased. The court rejected the claim filed by the unrepresented litigant, who then proceeded, over the course of more than a decade, to file hundreds of claims against that particular lawyer and his clients in an effort to reverse the decision. In this case the court considered the right of an individual not to be harassed, in addition to the systemic aspect surrounding the matter of serial litigants, and issued an injunction prohibiting that individual from initiating proceedings against the lawyer and his clients on any matter that related, even indirectly, to the subject of the class action. This was a limited injunction (similar to the one issued by Supreme Court President Grunis in the VK case) that applied only to a specific relationship in the context of a particular matter already 
decided by the courts, and therefore did not have a significant detrimental impact on the right of access to justice (Leibel $v$ Rotschild, 2016).

The second case (VK10), involved an injunction against further proceedings by Mike VK, who had already been issued a limited injunction by the Supreme Court president. Judge Orenstein found that VK had submitted hundreds of baseless claims for massive amounts of money, mostly against judicial officials, without having paid the fees for these claims or the costs imposed on him, while also strongly berating the court system. After the court itself cautioned that injunctions against further proceedings were to be issued only in extreme cases and noted that VK had no legal representation, it found that in light of the heavy costs caused by VK, there was a basis for issuing an injunction stipulating that he be allowed to turn to the Tel Aviv District Court only on the condition that the president has approved the complaint he wishes to file.

A Supreme Court ruling of July 2018 illustrates the two different approaches (Se2). The case involved a prisoner who had initiated hundreds of proceedings in various courts. The District Court issued an order stating that the prisoner would have to pay the court fees for any additional proceeding he initiated before the case would be considered (under normal circumstances, requests by prisoners to have a fee waived are considered during the course of the substantive proceedings, and the judicial ruling is issued before the fee is paid), further stipulating that he was entitled to file no more than two complaints once every two months, and no more than eight per year without paying fees. While the minority opinion held that this arrangement struck a proper balance between the right of access to justice and the harm caused to the court system by serial litigants, Supreme Court President Justice Hayut stated in the majority opinion that although it appears that the court has the authority to issue injunctions against further proceedings, the restriction on the right of access to justice in this particular injunction was overly strict. She referred to the fact that the claimant was a prisoner and consequently disadvantaged; that in practice the injunction as formulated grants a measure of discretion to the Israel Prison Service (which is likely to be the respondent in many of the prisoner's complaints) to determine which complaints to submit for judicial review; and to the fact that the injunction limits the possibility of initiating new proceedings, not only of reinitiating proceedings that have ended. She added that despite the severe systemic harm caused by serial litigants, courts were to refrain from denying their right of access to justice unless a law is passed that grants such authority.

Shortly before that ruling was issued, the Courts (vexatious litigants) Memorandum Bill, (2018) was introduced in the Knesset. The bill sought to grant courts the explicit authority to issue injunctions against further proceedings. The bill was approved by the government and passed a first reading, but it remains unclear whether it will be advanced further. The rationales behind the bill include systemic factors as well as the negative impact of proceedings on the serial respondents who had to deal with multiple frivolous claims. The proposed legislation would permit Supreme Court justices to issue injunctions against serial litigants, prohibiting them from filing civil or administrative complaints with the courts unless they have prior permission from a judge. Presidents of other courts would also be permitted to issue such an injunction, but it would be limited to the court over which they preside. The injunction would remain in effect for two years and could be extended for periods totaling no more than five years. The bill 
addresses the matter of prisoners separately, stipulating that injunctions against them would be permissible but would only remain in effect for a year and would be conditional on the prisoner having filed at least ten complaints in the previous year, all of which had been rejected or dismissed.

Our brief review indicates that Israel, in contrast to England and other countries, still lacks specific legislation on injunctions against further proceedings. To date, although the courts have debated the fundamental issue of their authority to issue such injunctions as well as the question of balancing the various considerations, there is no uniform trend in the case law. However, we can identify a number of guiding considerations. Courts are more likely to issue injunctions if they are aimed at protecting a specific person rather than protecting the court system itself from wasting resources, and the case law reveals a tendency to refrain from issuing injunctions against prisoners (even though the judicial system regards some of these prisoners as "serial litigants"). It also reveals a tendency to ascribe importance to differentiating between injunctions against the filing of complaints and injunctions that condition the filing of complaints on the payment of a fee. Ultimately, however, the judges' personal impression and the balance they strike among various principles play a key part.

\section{Profile of the serial litigant}

Having reviewed the policy considerations relevant to the phenomenon of serial litigants, the personality factors that might explain some of their conduct, and the state of the law in Israel, let us now discuss the serial litigants themselves and the personal background and story that drive them. This is an important discussion because, as noted, the serial litigants constitute a relatively small group who should perhaps be handled on an individual basis, or at least in a manner that takes into account the personal characteristics of serial litigants. Moreover, a presentation of the narrative of serial litigants is particularly important because to date no such presentation has been offered anywhere. It is also important in order to differentiate different groups of serial litigants. Our acquaintance with serial litigants during the course of this study indicates that they most of them may be classified into two primary categories. The first includes individuals whom the judges believe, or suspect, evidently suffer from some type of mental disorder; the second category includes (usually long-term) prisoners engaged in an unrelenting war against the system via the courts by means of extensive litigation. ${ }^{16}$

The information we compiled about the personal stories of serial litigants drew on a number of sources. We searched the courts' databases to identify the names of serial litigants, using the terms "serial plaintiff," "serial petitioner," "vexatious plaintiff," "injunction against further proceedings," "querulous," "querulant," "serial litigant," and the like (for a similar methodology, see Katvan and Shnoor 2018). Thus we managed to identify the names of the most prominent serial litigants (excluding family court) which we will present below. The judicial decisions, however, contain almost no information about the serial litigants themselves, aside from their names, and the narrative of the serial litigants, the querulants, remains virtually untold. We therefore conducted a parallel search on the Internet and in the press to find articles about serial

${ }^{16}$ On the legislator (in Texas) specifically addressing vexatious litigations submitted by inmates, see Chapter 14 of the Texas Civil Practice and Remedies Code. For an analysis of this legislation, see Colby (2000). 
litigants. Thus it was possible to form at least a partial picture of the categories of serial litigants and their common denominators. ${ }^{17}$ Notably, not all serial litigants appear in a search of the databases. One reason is that the computerized databases began operating only in the mid-1990s, and even then not all judicial rulings and decisions were incorporated; secondly, as a matter of default certain cases, especially family court cases, do not appear in the databases, and if they do, they do not include the parties' names, which means there is almost no way to identify serial litigants in the family court, even though they are actually likely to contain a large portion of the serial litigation (Bogoch et al. 2011, Bryant 2019).

The profiles we present below represent the most prominent serial litigants in Israel. However, the profiles do not purport to represent the full complexity of these figures. The purpose of our description is to provide a picture of their recurring narratives. We do not offer a diagnosis or attempt in any way to diagnose these individuals, nor do we have any pretense of doing so. Although the details presented below have been publicized, including in media interviews with some of the complainants, we have disguised their names in most cases (with the exception of Dov Alon, the first litigant).

\subsection{Complex personalities}

\section{Dov Alon}

The first serial litigant to be recognized as such by Israeli courts was Dov Alon. Born in 1917, Alon first became known to the Israeli public in 1952, after filing a criminal complaint against a police officer and the director of a mental hospital, charging that they had illegally locked him up, until he escaped their custody. The minister of justice dismissed the complaint (Herut 1952), and Alon filed a tort claim for false imprisonment against both of them and several others, claiming he had been wrongfully locked up because he had discovered that embezzlement was taking place in the moshav (agricultural settlement) where he resided (Al Hamishmar 1954). In their defense, the respondents argued that Alon had burst into the police station, ranting and barking like a dog, and was therefore transferred to psychiatric care (Herut 1954). Alon's testimony in court indicates a great deal of confusion (Geva 1954). We do not know how the case concluded, but presumably his claim was dismissed, as indicated by the fact that Alon was indicted for defamation of the district court judge who heard his case (Davar 1955, Zmanim 1955), after Alon disseminated a letter against the judge. This second trial received a good deal of newspaper coverage. Alon represented himself in court, was found guilty, and received a sentence of a fine and probation. The court observed that "the defendant makes a strange impression, but I do not doubt (...) that he is of sound mind. The defendant followed the proceedings with interest and enthusiasm and

\footnotetext{
17 Our request that the Courts Administration provide data about serial litigants was denied by the administration of the Courts (Saban-Safrai, in email to Eyal Katvan, 13 November 2018: "The requested data (excluding the number of proceedings initiated and number of proceedings concluded, by year) cannot be generated in the manner requested on the basis of the reports available in the courts' computer systems. We note in this context that the Supreme Court's computer system does not include the indication 'serial proceedings filer.' Producing credible data would require a manual review of the cases themselves, and in any event this would be an unreasonable allocation of resources."
} 
responded as needed. Therefore the court did not deem it necessary to have him undergo a psychiatric evaluation" (Herut 1955).

A few years later Alon, who worked as a truck driver, received two traffic tickets. He sent letters of complaint to the police, "and the wording of the letters seemed strange to the traffic division personnel." The letters were sent to the Department of Motor Vehicles because it was suspected that Alon had a mental disorder, and subsequently he was referred for psychiatric evaluation as a condition for the renewal of his license. Alon turned to the Supreme Court (sitting as the High Court of Justice) but the Supreme Court president rejected his petition, noting that "the petitioner filed an assortment of papers, and his petition includes such a mix of things that the court cannot determine what he wants." (LaMerhav 1963) Because Alon refused to submit to a psychiatric evaluation, his license was revoked, and he then submitted a claim for damages against the state (Maariv 1968). His claim was denied on the basis of his earlier hospitalization, in 1952, among other reasons, and he appealed to the Supreme Court.

Media reports on the trial reveal the limits of tolerance for the different at that time: "Accompanied by sounds of laughter, this week the Supreme Court in Jerusalem heard the appeal of a man who claims that the authorities are persecuting him." In his appeal, Alon testified that he earns a living by driving a truck, "even for the purpose of paying the fees for the many High Court of Justice petitions I file" (Maariv 1968). Disappointed by the outcome of the proceedings, Alon sent abusive letters to the judges and was arrested pending trial. The court convicted him and passed a sentence that included time already served as well as probation. The court was of the impression that the defendant was mentally unstable but still fit to stand trial (Hatzofeh 1968).

After his release, Alon carried out protests in front of the court, demanding to have his license reinstated (Al Hamishmar 1969). Concurrently he filed a criminal defamation suit against the editors of a major newspaper in Israel for having published a report stating that he had publicly announced that he had sued all the Supreme Court justices. He charged that in doing so, they had subjected him to "ridicule and mockery." Needless to say, his claim was denied (Davar 1971).

Although we were unable to locate documentation related to additional claims, evidently Alon continued to file numerous complaints until 1975, when the district court decided to issue an injunction against further proceedings. As noted, the Supreme Court revoked this injunction on the grounds of lack of authority. Some years later Alon was sentenced to six months in prison for "contempt of court" (Battlehaim 1979). In media reports regarding his appeal from this decision, Alon was already labeled a familiar figure in the court system and someone who "bombards courts with dozens upon dozens of complaints against public figures and judges," whom he also denigrates (Battlehaim 1979). During the proceedings, Alon refused to retract his remarks. The court held that "being long acquainted with the appellant, I did not expect him to seize the opportunity presented to him (...). Someone who lives within society must not deviate from the minimal accepted standards of that society; the defendant is unwilling to comply; and someone who is unwilling to comply, must pay the price."

Only a few of the decisions regarding Alon have been published. Mainly the one dealing with the injunction against further proceedings, which paradoxically, was perhaps the only ruling in Alon's favor: he retained the right to continue submitting appeals and 
petitions, in spite of everything. This is evidence of the importance of serial petitioners as well - Alon brought about a ruling that upheld the right of access to justice.

IMAGE 1

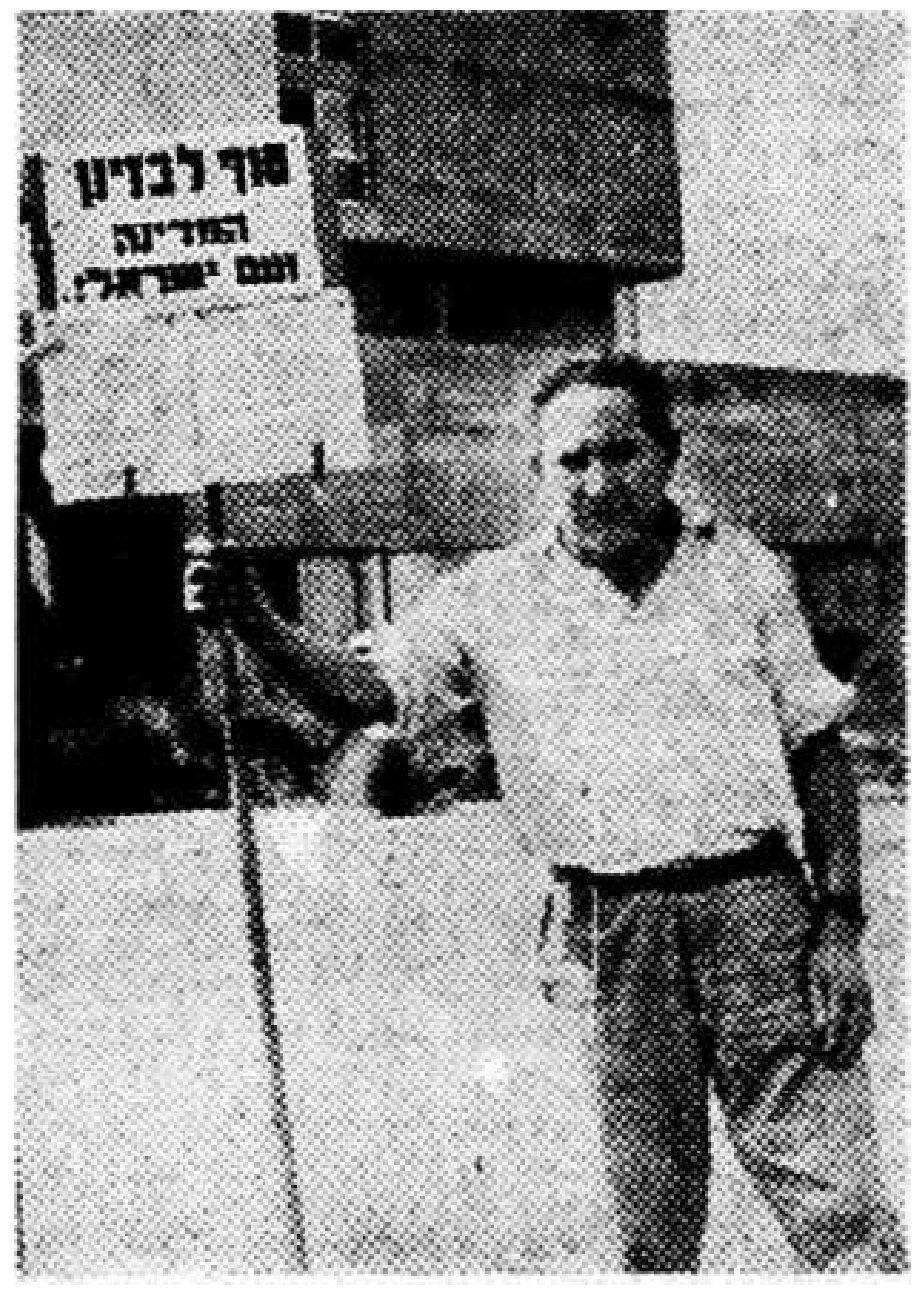

Image 1. Mr. Dov Alon in protest.

Alon's profile includes many elements that typify at least a significant portion of serial litigants: a basic grievance that he wishes to rectify; a complex personality that leads to friction with the law; self-representation that (perhaps as a direct consequence?) leads to a loss in court with which he is unwilling to reconcile; and resort to increasingly nonstandard measures, including action directed against the judges themselves, which exacerbates the dispute and repeats the cycle. ${ }^{18}$

\section{$\underline{\mathrm{SH}}^{19}$}

$\mathrm{SH}$, the oldest of eight children, was born in Iraq in 1951. His father, who had been active in the Zionist underground according to $\mathrm{SH}$, immigrated to Israel before the rest of the family and settled in Jerusalem. At the age of six months, $\mathrm{SH}$ arrived in Israel with his

\footnotetext{
${ }^{18}$ Alon wrote a short autobiography from which one forms the impression of a tragic character who suffered a great deal. He had complete faith in the righteousness of his cause and no faith in government institutions, especially not in the court system.

${ }^{19}$ We found a total of 413 entries about his cases, of which about 50 involve petitions for a fee waiver, 20 deal with judicial disqualification, ten are directed against the defense company for employment termination, and ten against the city of Carmiel.
} 
mother, and in 1955 the family relocated to Kiryat Malachi. "We lived in an immigrant transit camp for a few years, until Dad, who had become a contractor, got us out of there and into a nicer home." (Ratner 2002) He graduated from a vocational high school and worked in communications while serving in the air force. He stayed in the army for a few years after the mandatory period and then had several different jobs, until he was hired by A defense company. He incurred debts in the course of moving to a new apartment, and in an effort to resolve the problem transferred to a secret facility in the Negev. A salary increase that he had been expecting but did not receive led to friction with his employer, which resulted within a few years in the defense company declaring him mentally unstable and "a possible threat to security." The company initiated a termination process, which lasted until 1994 because SH appealed to various entities, including the State Comptroller, where he filed complaints on matters that for the most part remain classified. After that he engaged in a lengthy struggle against the defense company and the State Comptroller, which branched off to include disputes with the courts and the Israeli president. According to him, he was dismissed "after alerting the State Comptroller to corruption at his workplace, in a secret experimental facility belonging to the defense company." He carried out his struggle both in the courts and through numerous one-man protests. His legal battles took a high toll on himself and his family. SH devoted his time to his various struggles and remained unemployed, which brought his family to the brink of starvation. Some years after his dismissal, one of his daughters passed away, which led to additional legal battles. In the course of his legal disputes, SH was examined by various mental health experts, whose opinions were divided. One expert found that "SH's persistent struggle is in my view the existential struggle of a man who is not ill but is willing to sacrifice important things in his life in order to achieve social moral goals that he views as noble and whose attainment supersedes other goals." (Ratner 2002) Two other experts found that he was suffering from delusions of persecution.

After his first complaint against his employer was dismissed, he swamped the courts with suits and petitions on various issues. Some addressed personal matters: a criminal complaint for defamation (SH12), a demand for reinstatement of employment (SH13), and a claim against the National Insurance Institute (social security) for recognition as a "house husband" and on charges of sexual discrimination (SH5), among others (SH1; $\mathrm{SH} 5)$. Others were of a public nature: investigation of a military training accident (SH9) and revocation of a ministerial appointment (SH7), among others (SH2). All of these cases were accompanied by numerous proceedings, including petitions for a waiver of fees and dismissal of costs imposed on him (SH8); requests for judicial disqualification (SH4); charges of negligence against judges who had heard his cases (SH3); and even a petition against the State Comptroller (SH10). He represented himself and tended to use harsh language, including insults and derision, in his legal conduct, albeit to a lesser extent than other serial litigants. The volume of his complaints reached such a point that the court registrar raised the possibility of injunctions against further proceedings by serial litigants (SH11). According to SH, however, such an injunction would not lead him to reduce the volume of his complaints because he felt they were existentially necessary. The judicial system was the arena in which he could tell his story, but he was prevented from doing so, usually for procedural reasons (payment of fees). Like Alon, he carried out protests. Apparently he was seeking to share his story (for example with police 
officers who approached his protests in front of the president's residence) (Ratner 2002). His losses in court only intensified his struggle, to the extent that he felt persecuted by the judicial system itself. In an interview he stated that "I want to change the world order. I do not want anyone in Israel to undergo what I underwent, to be shattered by a large and powerful system" (Ratner 2002).

\section{$\underline{\mathrm{SO}}$}

Another example of this type of serial litigant is $\mathrm{SO}$, a divorced man facing financial hardship (So7). So first appeared in the databases in 1995, when his petition for a fee waiver during an appeal to the Supreme Court was denied. Two years later SO appealed to a district court after having been charged in absentia in traffic court. In his appeal, SO wrote, "In denying my petition for a hearing in light of the above (...) the conduct of Judge Doron was, in my view, anti-Semitic and racist because I wear a kippah [skullcap] and have a thick beard." (SO5) This statement led to charges of contempt of court (SO5). He was convicted and appealed to the district court. The majority opinion denied his appeal, mainly on the grounds of protection of judicial institutions (similarly to the court opinion in (VK3). The Supreme Court rejected SO's subsequent appeal of this ruling (SO6). So then filed petitions for a retrial on the charges of contempt of court and the traffic violation. Simultaneously he was also engaged in a series of other lawsuits he initiated, some of which began in small claims court but ended up in the Supreme Court (SO2). To these he added various petitions against the heads of state, including the prime minister and the president of the Palestinian Authority, "requesting that the two of them align themselves with God's Torah and conclude that there is no room for two states in the land of Canaan." (SO3). He even submitted a claim against the Hebrew Language Academy requesting "rehabilitation of the concept 'woman' in the Hebrew language" (SO1) and against "the People of Israel across the generations" (SO4). He signed one of his Supreme Court petitions, "A Prophet like Moses, Messiah to the World," stated that he was acting "on behalf of the Creator and has messages from Him; and that it is necessary to hold a hearing regarding them in this court in order that we might share the heavy responsibility for the fate of the world that rests on his shoulders" (SO7). His financial situation forced him to submit numerous requests for fee waivers and for appeals and petitions when his requests were denied. Here too, despite the dearth of biographical details, one has the impression that the pattern of earlier examples was repeating itself.

\section{$\underline{\mathrm{VK}}$}

VK was born sometime around 1943. We found more proceedings in which he was involved than we did for any other serial litigant - about a thousand. "He is an estranged father of four who suffers from a variety of complex physical disabilities. According to his own medical expert, he suffers from 'a delusional disorder, persecutory type' and apparently was forcibly hospitalized in a mental institution in the past" (VK11). He was living on the street, unemployed, subsisting "from hand to mouth" (VK5) on a meager disability pension, and had been declared bankrupt. Over the years he filed dozens of requests for a continuance, petitions for fee waivers (which the court itself realized led to ever more complaints, appeals, and petitions resulting in a "vicious cycle" of proceedings) (VK7), and requests for judicial disqualification, using particularly harsh language. (For example, he described the court registrar as "better suited to serve as a 
judge in the Revolutionary Guard of present-day Persia and/or as a court-martial in a totalitarian state.") (VK6). He also filed suits for damages after losing his cases, in one instance for $€ 22$ million (VK9).

Over the years VK earned notoriety, for better or worse, as a serial litigant. Like other serial litigants, he usually had no legal representation and often used forceful language in addressing the court (VK6). He managed to set a number of precedents: when the president of the Supreme Court issued a limited injunction against further proceedings, prohibiting him from pursuing cases that had already been decided (VK8); when the president of the Tel Aviv-Jaffa District Court issued a broader injunction against him (VK10); and when he was charged with contempt of court in response to written remarks during various proceedings and sentenced to four months of community service (VK1). At the same time, the court also took his circumstances into consideration. For example, when he was ordered to pay his creditors 50 New Israeli Shekels (NIS) per month, the court considered his situation and dismissed all his debts: “The debtor's age and poor state of health suggest that even if he pays the sum of 50 NIS per month until the age of 120, his creditors would not benefit, on the one hand, and he would suffer humiliation and a loss of dignity, on the other. How would it benefit the creditors if the debtor were unable to eat for one or two days per month? Not to mention other needs such as shelter, medical care, and the like." (VK5).

In 2017 the Supreme Court president (Hayut) heard a case that reflects the nature of relations between VK and the court system. The case involved a request by the president of the Tel-Aviv-Jaffa Magistrate Court to transfer proceedings from his district to another district. The case he wished to transfer involved a request by the state to issue an injunction against VK prohibiting him from initiating any proceedings whatsoever in courts within the district. According to the magistrate court's president, the request was based on the inappropriateness of judges considering a request for an injunction that would bar access to courts in their own district. According to the state, however, the request of the magistrate court's president was based on the fact that many magistrate court judges had been personally sued by VK. The Supreme Court president denied the request for a transfer, stating that "the court has the authority to examine the way in which it addresses a party who abuses the right of access to justice and unnecessarily burdens it. For many reasons it even seems that the 'harassed court' is the appropriate venue for examining and considering the means of coping with the serial litigant, in light of its unmediated familiarity with him as a vexatious litigant" (VK2). VK naturally continued to turn to the courts after this ruling, and since the beginning of 2018 about thirty judicial rulings in his matter have been issued.

Here too, the picture that emerges is of a person who is suffering, who initiates numerous proceedings in which he represents himself in an aggressive manner, refusing to cooperate with lawyers appointed to him. A person who sees every loss as the initiation point of numerous new proceedings and who fosters a sense of being the victim of the judicial system.

\subsection{Prisoners}

The second category of serial litigants comprises prisoners. This group is harder to define, aside from the basic condition that all its members are prisoners sentenced to 
many years behind bars, who spend their days filing various claims, be they against the prison authorities on matters related to their incarceration or on other matters.

\section{$\underline{\mathrm{M}}$}

M, a resident of Jenin, was sentenced in 1996 (at the age of 26) to 21 years and 5 months for rape, larceny, grievous bodily harm, and unlawful entry to Israel. He was released in January 2018. ${ }^{20}$ In some of his petitions he was represented by the public defender or legal clinics, and in others he represented himself. The court classified some of M's petitions as substantive and related to the terms of his incarceration and those of prisoners in general: restrictions on contact with the media, denial of food and of opportunities to relieve oneself during transport to court proceedings or medical care; the prison guards' treatment of him and their handling of prisoners' complaints; and requests for unprocessed meat, among others. He was labeled a "serial petitioner" which sometimes resulted in the court levying expenses on him (M2) and even the occasional dismissal of his petitions. ${ }^{21}$ Often the petitions he submitted on his own were dismissed without consideration, for lack of clarity (M1), or due to his harsh manner of expression. Nonetheless, some of his petitions led to systemic changes, and in this sense he served as a class-action plaintiff on behalf of prisoners (See e.g. M5), in a few cases even earning praise from judges. Even when he filed suits against the Prison Service and its employees in small claims court, he received a sympathetic ear. In one case involving a suit for damages on the grounds that the terms of his incarceration had unlawfully been made more stringent, the court denied the state's motion to "dismiss the claims without consideration on the grounds that they are vexatious and the claimant is a 'serial' petitioner," and it granted M damages amounting to $€ 2,200$ as well as court costs of $€ 110$ (M3).

An article published after his release (Glazer 2018) reveals that he views himself as a champion of prisoners' rights. He was particularly proud of a petition he had submitted following the release of a World Health Organization report stating that processed meat is harmful to health, on the basis of which he had petitioned to receive unprocessed meat. On the other hand, it appears that he often acted like a "troll" whose main objective was to harass the system. This is also the impression that emerges from a ruling that found that he was using petitions as a tactical tool in order to be transferred to a prison closer to his home. According to the ruling, $\mathrm{M}$ opted for the approach of serial petitioning against every Prison Service procedure until the Service will give in. ${ }^{22}$ Throughout the

\footnotetext{
${ }^{20}$ We found 492 rulings in his matter, most of which are petitions by inmates against the Prison Service, including 100 appeals.

21 "In the process of considering how to handle publication by a prisoner, I am convinced that at least some weight should be given to the burden the specific prisoner places on the respondent (...). The petitioner has submitted several dozen prisoner petitions, some of which have reached the docket of this court in the form of requests to appeal. Not for naught did Justice Procaccia, in PLA 10888/08, note that the claimant is a'serial petitioner who indiscriminately inundates the Supreme Court with requests to appeal'. In light of this, I am not convinced that the petitioner represents the typical prisoner, and for this reason as well, his case does not merit appeal" (M4).

22 "The petitioner submitted a large number of petitions. This is a prisoner at Damon Prison who has declared before me that he would keep filing petitions continuously as long as the Prison Service does not grant his request to be transferred back to a prison in the south. When the petitioner chooses this mode of conduct, it is necessary to consider the appropriateness of imposing court costs that will reflect this mode of behavior" (M6).
} 
years he operated systematically and deliberately, forming coalitions with other prisoners, cooperating with other serial petitioners in the prison and using all the help he could get from the public defender and other lawyers any time he could obtain it, setting him completely apart from the profile of the lone litigator in the category discussed earlier.

The article on $\mathrm{M}$ describes two approaches by the District Court towards him:

When $\mathrm{M}$ loses, which is not infrequent, he always turns to a higher court. His experience indicates that this sometimes paid off, even when the appeal did not overturn the original ruling. This was the case with his petition regarding the unnecessary transport of prisoners to court hearings, when in retrospect it turned out that the hearings had been postponed or canceled. $\mathrm{M}$ appealed through a lawyer (...) requesting that the courts and Prison Service synchronize their timetables. The petition was denied by the administrative court in Be'er Sheva on the grounds that these were isolated instances that did not justify intervention, but $\mathrm{M}$, as usual, sought to appeal. The Supreme Court justices did not deny the appeal, but instead instructed the Prison Service to conduct a pilot project (...). As far as $\mathrm{M}$ was concerned, this amounted to recognition of the phenomenon. And indeed, during the summation of findings the Prison Service committed to its minimization. In their decision to reject the petition, the justices noted, 'The request before us and the proceedings that took place undoubtedly contributed to the elimination of a worthwhile issue.' Justice Yoram Danziger even complimented M and described him as someone who had 'done an important public service in his matter and a matter of concern to others.' (Glazer 2018)

However, not all the judges were as tolerant. In fact more often the response to $\mathrm{M}$ was hostile, given his classification as a serial petitioner. Justice Ayala Procaccia wrote in one of her decisions that $\mathrm{M}$ "indiscriminately inundates the Supreme Court with requests to file appeals" and her colleague Asher Grunis referred to "a petitioner who files countless petitions, to the extent that it is difficult to follow them."

The article about him also used two contrasting nicknames: "troll" on the one hand and "Don Quixote" on the other (Glazer 2018).

\section{$\underline{\mathrm{SE}}$}

SE, born in 1970, was convicted of a long series of serious sexual offenses. He was sentenced to 35 years in prison, the longest sentence a sex offender had received in Israel at the time. In 2006 he managed to escape, was apprehended two weeks later and sentenced to four additional years. He was born and raised in Tel Aviv. In sixth grade he moved to a kibbutz (without his family) on the recommendation of a social worker. As a child, he had witnessed his alcoholic father commit suicide by jumping off an electric pole. At his trial he claimed that his "problem" (referring to his urge to rape) stemmed from abuse by young women on the kibbutz and childhood experiences with his mother.

Over the years he initiated hundreds of proceedings, the vast majority of them against the Prison Service and State of Israel. He sued the Prison Service and guards who, according to him, were responsible for the loss of his personal file; he sued a prison social worker for sharing things he had told her with others. He also sued a cellmate for distributing his property; and Yediot Aharonot newspaper for harm to his reputation and "libel" in its articles about him; and the list continues. He filed petitions against the 
Prison Service on a diverse range of issues, such as demanding that it provide him with bags of fruit and vegetables, preserve his rights while in solitary confinement, send his requests and petitions, and return documents to him, among others.

In 2011, the Be'er-Sheba district court set guidelines for handling future petitions by SE (SE1), and held that SE could enjoy fee waiver only for a limited number of prisoner petitions. That same year the Supreme Court rejected his appeal of the ruling, but in 2017 President Hayut overturned this arrangement, holding that it was disproportionate and did not properly balance SE's right of access to justice with the public interest that supports limiting it.

In this case it is very difficult to determine whether there was an overarching strategy behind the petitions, whether they were intended to exhaust the authorities or pass the time during incarceration, or whether perhaps this was an individual who did not hesitate to exercise his rights to the fullest, and his legal actions were a response to what he considered violations of his rights, regardless of whether others view the matter as trivial or legitimate.

\section{Discussion}

Our analysis of the law relating to the prevention of serial litigation, together with the psychological literature on serial litigants, the comparison to hypochondriacs, and our presentations of the serial litigants themselves, yields a number of key insights.

One can identify common themes among many of the serial litigants in the first category. Nearly all are men over the age of $45 .{ }^{23}$ In most cases these are tragic figures who find themselves in a difficult situation that, perhaps because of mental disorder, led them to initiate a wave of legal action. It is possible that financial problems triggered the deterioration of their mental state, or that their mental problems fostered an addiction to litigation that in turn led to financial hardship. Sometimes it was a minor issue - such as parking violations or a driving license - that sparked their legal campaign. And sometimes the matter was more substantial - such as exposure of corruption. The result is a vicious cycle of lawsuits, petitions, appeals, requests for judicial disqualification, and fee waiver requests, with legal complaints that extend from the personal to the public sphere.

They view themselves as a modern "Don Quixote" - a name that recurs frequently in articles about and references to them. They are usually unrepresented, often because they have dismissed their lawyer or because their lawyer has resigned, which creates a dilemma for the courts: whether it might be preferable, in cases in which the right not to be represented is being abused, to limit this right rather than limit the right of access to justice (Rabeea 2015, State of Israel v Roppel, 2017, Whalen-Bridge 2019).

They regard the court as an arena in which to vent because it is important for them to share their story. If the court prevents them from doing so (and at one point or another most of them feel deprived of their rights by the courts), and even if does not, they will try to tell their story through protests and media outlets. They are often disappointed with the court but continue trying to operate within its framework. They assert that

\footnotetext{
${ }^{23}$ According to the Victorian Parliament Law Reform Committee (2008, pp. 34-35), the vast majority of serial litigants in both Australia and England are men between the ages of 30 and 50.
} 
injunctions against further proceedings will not deter them. That is, the usual barriers that are inherent to any judicial system in some form, serving to deter people from filing serial complaints - including barriers of time, lawyers' fees, court fees, embarrassment, emotional stamina, fear of loss, and the like - do not deter the serial litigant. In fact, for those who suffer from delusions of injustice, recourse to the courts is one of the manifestations of the mental state from which the serial litigant suffers. Accordingly, neither the various sanctions used against them on the one hand, nor substantive hearing of their case would bring the litigation to an end. Acceptance of their complaints would result in a new round of complaints, and rejection would prolong their struggle. Likewise, the lack of representation that characterizes these litigants is in part related (aside from their financial situation) to the mental state of serial litigants, who find it difficult to trust their lawyer.

The effect of courts' tolerance on the serial litigants themselves remains an open question that requires more research. It is unclear whether it serves as positive reinforcement which will strengthen the litigious behavior, or will it serve as s therapeutic process which will allow the litigant to cope with his situation in more socially acceptable behavior.

The fact that a serial litigant is identified as such does not always have an influence on the court. Even when it does influence the court, the influence can usually go both ways. However, in cases in which the judicial system feels threatened (and not only harassed) by these litigants' harsh manner of expression and personal attacks on the judges the influence will always be to the detriment of the serial litigant.

Prisoners, as a category, are both similar and different. They too regard the court as an arena to vent grievances. They too view themselves as fighting for justice (interestingly, they choose to fight in front of the court system which sentenced them to prison in the first place), at least retrospectively, but their primary objective might be to exhaust the system. Thus, while litigants in the first category pay a steep price for their struggle, prisoners actually benefit from it. Their petitions enhance their status in the prison, even though they are hardly empathy inspiring persons. In contrast to the first category, prisoners enjoy a relatively high degree of representation.

In matters related to prisoners' petitions, serial litigants serve an important social function because they enable a disadvantaged population to make itself heard in court. ${ }^{24}$ Accordingly, it is very important to maintain open access to justice for this group as a way of ensuring supervision of the prison services and preventing exploitation and abuse.

An interesting illustration to the ambiguous relationships between serial litigants and judges can be found in a dialogue between Dov Alon and Judge Binyamin Cohen, at the end of one of Alon's many trials. Before leaving the courtroom judge Binyamin Cohen implored the defendant, "Mr. Alon, after all, you like me, so why do you speak to me this way?" Alon angrily replied, "I don't like you!" Judge Cohen, who was exiting the courtroom with his colleagues, said, "But I actually like you, a little." Was Cohen being cynical, having wearied of his and the judicial system's confrontations with Alon, or had

${ }^{24}$ Cf. Reinert (2014) who distinguishes between frivolous cases that serve no social goal, and meritless cases that, despite lacking merit, may serve to expose social wrongs or lead to changes in the law. 
Alon in fact endeared himself to the judges in his own unique way? We shall never know.

\section{Conclusions}

The phenomenon of serial litigants is a reality of the Israeli legal system, as of legal systems elsewhere. This phenomenon adds to the already existing burden on the judicial system and on judges. It also creates impairments for other litigants: directly (for defendants and their representatives who must respond to legal complaints) and indirectly (for all those awaiting their day in court and for judges whose attention is detracted by dealing with vexatious litigation). In many ways, serial litigants are comparable to people who suffer from hypochondria. They too add burden to an already burdened system and reduce health personnel's ability to deal with other patients. And in both cases, it is hard to know at first glance whether their complaints conceal true (legal or medical) need.

Various legal systems, including some of the Israeli judges, have sought to place restrictions on serial litigants. We do not claim that such restrictions should not be imposed, but that they should be applied with caution and an understanding of the serial litigants' perspective. We have presented a number of perspectives from the "biographies" of serial litigants. Notwithstanding the burden they place on the courts and third parties, one cannot ignore these litigants' own suffering. The dichotomy is evident: they view themselves as Don Quixote, while others view them as trolls. The case law reflects this dichotomy: some rulings adopt a prohibitive approach, while others are based on acceptance and containment. ${ }^{25}$

In light of the above, our view is that in setting restrictions on serial litigants, attention should be paid to the following factors:

1. It is important to differentiate between the first type of serial litigants and the second type (prisoners), since in most cases they reflect different interests and motivations.

2. In some of the cases involving complainants with a problematic mental state, an injunction against further proceedings will not be effective.

3. The restrictions should make allowance for the difference between the two categories of serial litigants.

4. It is necessary to distinguish between serial litigants in total institutions (prisons or mental hospitals) and others, with the understanding that any complaints

\footnotetext{
${ }^{25}$ In our view, courts have an educational role. Courts often engage in educating parties about how to channel emotions (Katvan and Shnoor 2020). This function also serves to prevent disputes from spilling into the streets. Courts often educate litigators and their representatives during the actual course of proceedings, for example on inappropriate conduct and modes of expression (Katvan and Shnoor 2010). Ben Noon, Shnoor and Katvan (2015) demonstrated that frequently the judges themselves regard such conduct as akin to the behavior of children in nursery or elementary school. Here the situation is comparable to a problematic pupil whose disruptions affect everyone else and who must nevertheless be handled with patience and containment. The teachers and other pupils suffer from the disruptive behavior, of course, yet there is near consensus that only in extremely exceptional cases should the pupil be removed from school. It is understood that removing the disruptive pupil would not be effective and might only shift the unwanted behavior to the streets, but at the same time every effort is made to minimize the negative impact on other pupils and on the school.
} 
related to the fact or conditions of their incarceration or hospitalization require near-absolute leeway for the serial litigants.

5. It is necessary to distinguish between complaints in which the state is responsible for the legal defense (public authorities and public servants) and complaints in which the defendant is a private individual. Defendants who are private individuals should be protected from harassment, whereas some leeway might be in order when the state is the target of harassment, given that this is part of the Ministry of Justice role.

6. The restrictions should take into account the possible beneficial aspects of complaints for society as a whole. ${ }^{26}$ Channeling emotions to court and venting them in court might ensure the protection of important interests (for complainants and others) especially for prisoners.

7. Further research is needed to know whether allowing serial litigants and tolerating it, serves as a positive reinforcement which will only strengthen the undesirable behavior or whether it has therapeutic value which will better the plaintiff's situation.

Against this background, each individual case must, on its merits, balance the right of access to justice (especially for total institutions inmates) with the harm to the public, the judicial system, the judges, and other litigants, but also with the potential benefit for the public interests (ventilation; preventing violence; channeling emotions).

Finally, it is important to remember that even serial plaintiffs are sometimes wronged and need legal redress. Using Joseph Heller's words: "Just because you're paranoid doesn't mean they aren't after you" (Heller 1961).

\section{References}

Abel, R., 1973. A Comparative Theory of Dispute Institutions in Society. Law E Society Review [online], 8(2), pp. 217-347. Available from: https://doi.org/10.2307/3053029 [Accessed 10 January 2020].

Addad, A., 2013. Shimush Lera`a Behalikhei Beit Mishpat: Haganah Diyunit Mipnei Nitzul Lera'a shel Zkhut Hagisha Le'arka'ot [Abuse of Legal Process: Procedural Protection From Abuse of the Right of Access to the Courts]. Tel-Aviv: Bursi.

Al Hamishmar, 1954. Claims to have been locked up in a mental institution after discovering embezzlement. Al Hamishmar, 9 February, p. 7.

Al Hamishmar, 1969. Strike for the revoke of drivers`license. Al Hamishmar, 26 September, p. 12.

Albarracin, D., 2015. Narcissism and Object Relations in Hypochondria. Psychoanalytic Review [online], 102(4), p. 483. Available from: https://doi.org/10.1521/prev.2015.102.4.483 [Accessed 10 January 2020].

\footnotetext{
26 "SH takes his struggles to the extreme," according to Adv Eliyahu Zielgler, who has participated in some of his client's heroic struggles since 1993. "But Sh has an important societal role despite his extremism: he actually provides a 'peephole' into our society. Learn about what happened to him, his endless trials, and you will see through the prism of one man how our society tramples the weak who fall by the wayside, how the courts are in fact closed to most of those who are helpless." (Ratner 2002).
} 
American Psychiatric Association, 2013. Diagnostic and Statistical Manual of Mental Disorders [online]. Arlington: American Psychiatric Association. Available from: https://doi.org/10.1176/appi.books.9780890425596 [Accessed 10 January 2020].

Barak, A., 2013. The right to access the court. In: A. Grunis, E. Rivlin and M. Karyiani, eds., Shlomo Levin Book. Jerusalem: Harry Sacher Institute, p. 31.

Bar-Am, M., 2007. Frivolous civil litigation. Alei Mishpat, 6, pp. 135-210.

Battlehaim, A., 1979. Harsh words cost the defendant dearly. Maariv, 30 March, p. 6.

Ben-Ito, H., 1969. Private Complaint, Hapraklit, 25(3), p. 521.

Ben Noon, C., Shnoor, B., and Katvan, E., 2015. Judges' Perception of Lawyers' Behavior in Court. HaMishpat, 20, pp. 11-49.

Blee, K.M., and Billings, D.B., 1996. Violence and Local State Formation: A Longitudinal Case Study of Appalachian Feuding. Law \& Society Review [online], 30(4), pp. 671-706. Available from: https://doi.org/10.2307/3054114 [Accessed 10 January 2020].

Bogoch, R., Halperin-Kaddari, R., and Katvan, E., 2011. Family Law in the Age of Computerized Databases: The Impact of Legal Databases on the Practice of Family Law in Israel. Iyuney Mishpat, 34, p. 603.

Bryant, D., 2019. Access to justice: How much is too much? The legal and medical issues arising from vexatious or querulous people. Clayton: Monash University.

Colby, C., 2000. There's a new Sheriff in town: The Texas vexatious litigants statute and its application to frivolous and harassing litigation. Texas Tech Law Review, 31, p. 1291.

Davar, 1955. Indicted for slandering a district judge. Davar, 23 May, p. 4.

Davar, 1971. Yediot Ahronot editors acquitted from defamation charges. Davar, 23 April, p. 8.

Diesen, C., 2008. The justice obsession syndrome. Thomas Jefferson Law Review, 30, p. 487.

Elizur, A., et al., 1999. Prakim Nivkharim Bepsychiatria [Selected chapters in psychiatry]. Tel-Aviv: Dionon.

Freckelton, I., 1988. Querulent paranoia and the vexatious complainant, International Journal of Law and Psychiatry [online], 11(2), pp. 127-143. Available from: https://doi.org/10.1016/0160-2527(88)90026-X [Accessed 10 January 2020].

Gerevich, J., and Ungvari, G.S., 2015. The Description of the Litigious Querulant: Heinrich von Kleist's Novella "Michael Kohlhaas". Psychopathology [online], 48, pp. 79-83. Available from: https://doi.org/10.1159/000366562 [Accessed 10 January 2020].

Geva, Y., 1954. My client is not a dog. Mawariv, 23 February, p. 2.

Glazer, H., 2018. Ha`asir Shitril et Shaba"s Bemeshekh 20 Shana [The prisoner who trolled the prison service for 20 years]. Haaretz [online], 31 January. Available from: 
https://www.haaretz.co.il/magazine/.premium-MAGAZINE-1.5783193 [Accessed 10 January 2020].

Gueta, Y., 2014. Haraf Ha`elion Shel Grunis: Le`ayem Bepnia LaUm Vehashva`at Hamedina LeHamas [Grunis' upper limit: threatening to apply to the UN and comparing Israel to Hamas]. The Marker [online], 20 August. Available from: https://www.themarker.com/law/1.2410282 [Accessed 10 January 2020].

Hatzofeh, 1968. Imprisonment for hate letters on judges. Hatzofeh, 18 October, p. 7.

Heller J., 1961. Catch 22. New York: Dell.

Herut, 1952. Minister of justice canceled a complaint against police officer who locked up a person in a mental institution. Herut, 5 October, p. 4.

Herut, 1954. I was imprisoned in a mental institution so I won't disclose details of embezzlement. Herut, 9 February, p. 8.

Herut, 1955. Sentenced for slandering a district judge. Herut, 22 June, p. 4.

HM Courts and Tribunals Service of England and Wales, 2019a. General civil restraint orders in force [online]. Originally published in 2014. Available from: https://www.gov.uk/guidance/general-civil-restraint-orders-in-force [Accessed 12 June 2019]

HM Courts and Tribunals Service of England and Wales, 2019b. Vexatious litigants [online]. Originally published in 2014. Available from: https://www.gov.uk/guidance/vexatious-litigants [Accessed 12 June 2019].

Katvan, E., 2013. The “Overcrowding the Profession” Argument and the Professional Melting Pot International Journal of the Legal Profession [online], 19(2-3), 301. Available from: https://doi.org/10.1080/09695958.2013.772521 [Accessed 10 January 2020].

Katvan, E., and Shnoor, B., 2010. Between Civility and Reputation, Following C.A. 1104/07 Kheir v Gil. Hamishpat, 15, 71-110.

Katvan, E., and Shnoor, B., 2017. Informed Consent to Legal Treatment - Lessons from Medical Informed Consent. The International Journal of the Legal Profession [online], 24(2), pp. 125-144. Available from: https://doi.org/10.1080/09695958.2017.1280041 [Accessed 10 January 2020].

Katvan, E., and Shnoor, B., 2018. A Perfect Façade?: Transparency, Honor and Judicial Scarce Resources. International Journal of the Legal Profession [online], 26(1), pp. 143-158. Available from: https://doi.org/10.1080/09695958.2018.1490295 [Accessed 10 January 2020].

Katvan, E., and Shnoor, B., 2020. Sharui Oved Berogez: Kavod, Ka'as Umina'ad Rigshot Ha ovdim Bamishpat Halo Formali Betkufat Hamandat [Workers' Honor, Anger and Emotions in Mandate Palestine Informal Courts]. Law, Society and Cloture (Special Issue on Emotions, Tel-Aviv University).

Katvan, E., et al., 2017. Age limitation for organ transplantation: the Israeli example. Age and Ageing [online], 46(1), pp. 8-10. Available from:

https://doi.org/10.1093/ageing/afw162 [Accessed 10 January 2020]. 
LaMerhav, 1963. A motion for injunction against the DMV was denied. LaMerhav, 12 May, p. 6.

Lester, G., and Smith, S., 2006. Inventor, Entrepreneur, Rascal, Crank or Querulent?: Australia's Vexatious Litigant Sanction 75 Years On. Psychiatry, Psychology and Law [online], 13(1), pp. 1-27. Available from: https://doi.org/10.1375/pplt.13.1.1 [Accessed 10 January 2020].

Lévy, A., 1997. Rodfei Mishpat: Hahagshama Hasimlit: Mishpatim Beparanoia [Trial seekers - Symbolic realization: Trials in paranoia]. Jerusalem: Keter.

Lévy, B.T., et al., 2017. From Querulous to Suicidal: Self-immolation in Public Places as a Symbolic Response to the Feeling of Injustice. Frontiers in Psychology [online], 8, p. 1901. Available from: https://doi.org/10.3389/fpsyg.2017.01901 [Accessed 10 January 2020].

M1.

M2.

M3.

M4.

M5.

M6.

Maariv, 1968. After complaining about traffic police officers, his licence was revoked and he was summoned for mental examination. Maariv, 26 June, p. 11.

Merry, S.E., 1990. Getting Justice and Getting Even: Legal Consciousness Among WorkingClass Americans. University of Chicago Press.

Mullen, P.E., and Lester, G., 2006. Vexatious Litigants and Unusually Persistent Complainants and Petitioners, Querulous Paranoia to Querulous Behaviour. Behavioral Sciences and the Law [online], 24(3), p. 333. Available from: https://doi.org/10.1002/bsl.671 [Accessed 10 January 2020].

Noyes, R. Jr., et al., 2010. Hypochondriacal symptoms associated with a less therapeutic physician-patient relationship. Psychiatry [online], 73(1), pp. 57-69. Available from: https://doi.org/10.1521/psyc.2010.73.1.57 [Accessed 10 January 2020].

Paz, U.I., 2014. Sanctzia Takdimit: Fronis Horah Kemazkirut Beit-Hamishpat Lo Lekabel Bakashot Me oter Sidrati [Precedential sanction: Grunis ordered the court secretariat no to accept motions from a serial litigant]. Takdin, 21 August.

Rabeea, A., 2015. Injustice in Person: The Right to Self-Representation. Oxford University Press.

Rabin, Y., 1998. Gisha Le`arka`ot Kezhut Hukatit [Access to justice as a constitutional right]. Tel-Aviv: Bursi.

Ramachandra, N., 2013. Hypochondria-Historical Perspectives, Diagnosis and Management. Asian Journal of Nursing Education and Research [online], 3(4), pp. 219-223. Available from: http://ajner.com/AbstractView.aspx?PID=2013-3-4-5 [Accessed 10 January 2020]. 
Ratner, D., 2002. To go all the way. Haaretz, 21 August.

Reinert, A.A., 2014. Screening Out Innovation: The Merits of Meritless Litigation. Indiana Law Journal [online], 89(3), p. 1191. Available from: https://www.repository.law.indiana.edu/ilj/vol89/iss3/4/ [Accessed 10 January 2020].

Rowlands, M.W.D., 1988. Psychiatric and Legal Aspects of Persistent Litigation. The British Journal of Psychiatry [online], 153(3), p. 317. Available from: https://doi.org/10.1192/bjp.153.3.317 [Accessed 10 January 2020].

Se1.

Se2.

SH1.

$\mathrm{SH} 2$.

SH3.

SH4.

SH5.

SH6.

SH7.

SH8.

SH9.

SH10.

SH11.

SH12.

SH13.

Shammay, B., 2018. The supreme court sitting as the court of de minimis. Globes, 30 May.

SO1.

$\mathrm{SO} 2$.

SO3.

$\mathrm{SO} 4$.

SO5.

SO6.

SO7.

Taggart, M., 2004. Alexander Chaffers, and the Genesis of the Vexatious Actions Act 1896. The Cambridge Law Journal [online], 63(3), p. 656. Available from: https://doi.org/10.1017/S0008197304006713 [Accessed 10 January 2020]. 
Victorian Parliament Law Reform Committee, 2008. Inquiry into Vexatious Litigants. Parliamentary Paper No. 162, Session 2006-2008.

VK1.

VK2.

VK3.

VK4.

VK5.

VK6.

VK7.

VK8.

VK9.

VK10.

VK11.

Waitzkin, B.H., and Waterman, B., 1974. The Exploitation of Illness in Capitalist Society. Indianapolis: Bobbs-Merrill.

Whalen-Bridge, H., 2019. Surviving Litigation: Talking Law with a Litigant in Person. Paper presented at the "Too much litigation?" workshop. Onati International Institute for the Sociology of Law, 27-28 June.

Zmanim, 1955. Slandering the judge. Zmanim, 23 May, p. 4.

\section{Laws and statutes}

Civil Practice and Remedies Code (Texas).

Code of Civil Procedure (1872) (California).

Courts (vexatious litigants) Memorandum Bill (2018) (Israel).

Federal Court Act 1985 (Canada).

Judicature Act 1908 (New Zealand).

Senior Courts Act 1981 (Eng.).

Vexatious Litigant Act 1981 (Queensland).

Vexatious Proceedings Act 2008 (New South Wales).

Case law

Alon v State of Israel (1975a). CA 181/75 PD 29(2) 124.

Alon v State of Israel (1975b). CA 566/74 (HM 10647/74).

Am Shalem v Lifschits [2003]. HCJ 4676/03.

Arpal Ltd. v Kalil Industries Ltd., [1997]. CA 733/95 P.D. 51(3) 577.

Friskel v Orenstein (1996). LCA 714/96 PD 49(5) 759. 
Inter-Lab Inc. v Israel Bio Engineering Project, 2003. LCA 778/03 PD 57(5) 769.

Leibel v Rotschild, 2016. CC (TA) 2446/06.

Ombudsman of Israeli Judiciary, 2016. Decision 196/16. 19 April.

State of Israel v Roppel, 2017. LCA 2097/16.

Y. v Y., 2010. Fam (Jer) 25202-09-10.

Y.Y.E. v M.T., 2016. FamA (TA) 16608-11-14.

Zomris $v$ Weiss, 2004. LCA 3277/04. 